\title{
EVALUATION OF ANTIDIABETIC ACTIVITY OF ZANTHOXYLUM OVALIFOLIUM LEAF EXTRACTS
}

\author{
ARUN K. ${ }^{*}$, VIRUPAKSHA J. H. \\ Department of Pharmacology, National College of Pharmacy, Balraj Urs Road, Shivamogga 577201, Karnataka State \\ Email: arunakon267@gmail.com
}

Received: 26 Mar 2020, Revised and Accepted: 12 Dec 2020

\begin{abstract}
Objective: The present study was aimed to investigate the antidiabetic activity of ethanolic and aqueous extract of Zanthoxylum ovalifolium on alloxan induced diabetic rat model in rats.

Methods: The leaves of Zanthoxylum ovalifolium were evaluated for antidiabetic activity by using alloxan induced diabetic model in diabetic rats. Diabetes was induced by single intraperitoneal injection of alloxan (100 mg/kg) and rats were treated orally with test extracts, standard drug (glibenclamide $5 \mathrm{mg} / \mathrm{kg}$ ) and vehicle for $21 \mathrm{~d}$. The hypoglycemic effects and lipid profile of diabetic rats were assessed using diagnostic kits. Finally, histopathological studies were carried out for pancreas.

Results: The acute toxicity studies revealed at the dose of $2000 \mathrm{mg} / \mathrm{kg}$ (b. w) of Zanthoxylum ovalifolium for ethanol and aqueous extract were found to be safe. A significant reduction $(\mathrm{p}<0.001)$ in blood glucose was observed in diabetic rats treated with different doses of extracts compared to untreated diabetic rats. The drug possesses a good hyperlipidemic effect by normalizing the lipid parameters. This was evidenced by histopathological studies; both glibenclamide and $400 \mathrm{mg} / \mathrm{kg}$ of Ethanolic extract does appear to be regulated diabetes at the cellular level, resulting
\end{abstract} in the restoration of near normal architecture pancreatic islet of langerhans.

Conclusion: It can be concluded from our research findings that ethanolic and aqueous extract of Zanthoxylum ovalifoliumat high dose (400 mg/kg) exhibited significant antihyperglycemic activity than extract at low dose $(200 \mathrm{mg} / \mathrm{kg})$ in alloxan induced diabetic rats. These extracts also showed improvement in parameters like lipid profile as well as regeneration $\beta$-cells in the pancreas and so might be of value in diabetes treatment.

Keywords: Zanthoxylum ovalifolium, Antidiabetic activity, Lipid profile, Alloxan and glibenclamide

(c) 2021 The Authors. Published by Innovare Academic Sciences Pvt Ltd. This is an open access article under the CC BY license (https://creativecommons.org/licenses/by/4.0/)

DOI: https://dx.doi.org/10.22159/ijpps.2021v13i2.37636. Journal homepage: https://innovareacademics.in/journals/index.php/ijpps.

\section{INTRODUCTION}

Diabetes mellitus is a heterogeneous metabolic disorder characterized by the common feature of chronic hyperglycemia with disturbance in carbohydrate, fat and protein metabolism [1]. It defects in insulin secretion, insulin action or both [2]. Diabetes mellitus is represented by hyperglycemia, lipidaemia and oxidative stress [3]. It is recognized as a major global chronic health problem, accounting for significant morbidity and mortality; it is associated with microvascular (retinopathy, neuropathy and nephropathy) and macrovascular (heart attack, stroke and peripheral vascular disease) complications [4]. The International Diabetes Federation (IDF) estimates that in 2013, the number of people suffering from diabetes was 382 million, while 5.1 million died, and that this prevalence will rise to 592 million by 2035 [5]. Though there are several synthetic drugs available for reducing the blood glucose levels, such as sulfonylurea, biguanide, thiazolidinedione, $\alpha$-glucosidase inhibitors, and glinides. Patients continue to suffer from the several adverse effects of these synthetic drugs due to which, to explore a for new herbal drug is going on and concerted efforts are being made to develop suitable alternative effective remedies for diabetes [6, 7]. Presently, there is a growing interest in herbal remedies that are apparently efficient, produce minimal side effects, and are rich sources of antidiabetic, antihyperlipidemic and antioxidant agents such as flavonoids, tannins and other related polyphenols [8].

The Zanthoxylum ovalifolium has been widely used for traditional medicine in various types of illness. These plants are deciduous shrub and trees belonging to the family Rutaceae, which consists of 250 species native to subtropical regions of the world [9]. The genus is rich source of various chemicals such as alkaloids, glycosides, flavanoids, phenols, steroids, tannins, terpenes and amides etc. [10]. Information provided by traditional healers in the Western Ghats indicates that the leaf of Zanthoxylum ovalifolium is used to treat diabetes and hypertension. However, there is a lack of sufficient scientific data proving the traditional use of Zanthoxylum ovalifolium in the treatment of diabetes. Hence there is an increasing need of a new natural antidiabetic agent with less adverse effects; safe and easily available. So, the present investigations were undertaken to evaluate the effects of the ethanolic and aqueous extracts resulting in antidiabetic activity in alloxan-induced diabetes in rats.

\section{MATERIALS AND METHODS}

\section{Plant material}

The leaves of Zanthoxylum ovalifolium were collected from the Agumbe village of Thirthahalli Taluk, Shivamogga district of Karnataka and were authenticated by Dr. Rudrappa, Professor and H. O. D Dept. of Botany, S. R. N. M National College of Applied Science, Balraj Urs road, Shivamogga, Karnataka state. A voucher specimen of the plant was preserved in the herbarium (Specimen No. 506/201617) deposited in the Pharmacognosy Department, National College of Pharmacy, Shivamogga for further reference.

\section{Preparation of the extracts}

The leaves of Zanthoxylum ovalifolium were cleaned and dried under shade at room temperature for several days and coarsely powdered. The powdered material was extracted successively with different solvents viz. Petroleum ether, ethanol in a Soxhlet extractor for $48 \mathrm{~h}$ in 4 batches of 50 each. The extract was concentrated in a vacuum using rotary flash evaporator (Buchi, Flawil, Switzerland). The marc obtained after ethanolic extraction is kept in contact with distilled water for $48 \mathrm{~h}$ with occasional shaking in the stoppered container for cold maceration process. The extract is concentrated under reduced pressure and stored in a refrigerator for further use.

\section{Experimental animals}

Healthy wistar albino rats of either sex weighing about 200-250g were selected in the present experimental study. The animals were procured from Central Animal House, National College of Pharmacy, Shivamogga. After randomization into various groups, animals were acclimatized for a period of $10 \mathrm{~d}$ under standard husbandry 
conditions. The rats were fed with a standard pellet diet and water ad libitum. The experimental protocol was approved by the Institutional Animal Ethical Committee (IAEC) of National College of Pharmacy, Shivamogga, Karnataka (Approval No. NCP/IAEC/ $\mathrm{CL} / 06 / 2016-17)$ and care of the animals was taken as per guidelines of the CPCSEA.

\section{Chemicals}

Alloxan and glibenclamide were purchased from Sigma-Aldrich and Sun Pharmaceuticals, respectively. All other reagents used during the experiments were of analytical grade.

\section{Phytochemical analysis}

Preliminary phytochemical studies of both the extracts were performed as per standard procedure $[11,12]$.

\section{Acute toxicity test}

A preliminary toxicity study was conducted to demonstrate the appropriate safe dose range that could be used for subsequent experiments rather than to provide complete toxicity data on the extract. Acute toxicity studies conducted revealed that the administration of the ethanolic and aqueous extract (up to a dose of $2000 \mathrm{mg} / \mathrm{kg}$ ) of Zanthoxylum ovalifolium leaves did not produce significant changes in behavior of the animals. No death was observed up to the dose of $2000 \mathrm{mg} / \mathrm{kg}$ b.w. The rats were physically active. These effects were observed during the experimental period $(14 \mathrm{~d})$. The results showed that in a single dose the plant extract had no adverse effect, indicating that the medium lethal dose $\left(\mathrm{LD}_{50}\right)$ could be greater than $2000 \mathrm{mg} / \mathrm{kg}$ body weight in rats. In the acute toxicity study, no toxic symptoms were observed for Zanthoxylum ovalifolium up to the dose of 2 $\mathrm{g} / \mathrm{kg}$ body weight. All animals behaved normally. No neurological or behavioral effects could be noted. No mortality was found up to 14 d study [13].

\section{Induction of diabetes and experimental design}

After fasting, hyperglycemia was induced by i. p. injection of 100 $\mathrm{mg} / \mathrm{kg}$ of alloxan monohydrate in sterile saline administered for induction of diabetes in rats [14]. After $1 \mathrm{~h}$ of alloxan administration, the animals were fed standard pellets and water ad libitum. The rats were then kept for the next 24hours on $10 \%$ fructose solution bottles in their cages to prevent hypoglycemia. After $72 \mathrm{hr}$ of Injection, fasting blood glucose levels are estimated. Rats showing fasting blood glucose level of more than $200 \mathrm{mg} / \mathrm{dl}$ were considered as diabetic and selected for the study [15]

The experiments were conducted on animal groups to see the effect of Zanthoxylum ovalifolium leaves on diabetic rats. Six rats were used in each of the seven groups, which were as follows

The animals were divided into seven groups of six animals each as follows.

Group I: Normal control rats treated with vehicle $0.5 \mathrm{ml}$ of $5 \%$ tween 80

\section{Group II: Diabetic control received vehicle}

Group III: Diabetic rats treated with standard drug glibenclamide (5 $\mathrm{mg} / \mathrm{kg}$ b. w.).

Group IV and Group V: diabetic rats treated with EEZO (200 mg and $400 \mathrm{mg} / \mathrm{kg} \mathrm{b.} \mathrm{w.),} \mathrm{respectively}$

Group VI and Group VII: diabetic rats treated with AEZO (200 mg and $400 \mathrm{mg} / \mathrm{kg}$ b. w.) respectively. The vehicle, EEZO, AEZO and glibenclamide were administered once daily for $21 \mathrm{~d}$ from the day of induction.

\section{Blood glucose estimation}

Blood was drawn from tip of the tail, and blood glucose level was estimated at $0,7^{\text {th }}, 14^{\text {th }}$ and $21^{\text {st }}$ day of the experiment with the help of a glucometer (GluNEO ${ }^{\circledR}$ Lite (INFOPIA Co Ltd) using the strip method. On the $21^{\text {st }}$ day, the blood sample was collected by puncturing retro-orbital plexus and serum was separated by centrifugation for measuring total cholesterol (TC), triglycerides (TG), high-density lipoprotein (HDL), low-density lipoprotein (LDL) and very-low-density lipoprotein (VLDL) levels were evaluated in all groups using an auto-analyzer (Semi-auto chemistry analyzer DIA SIL-100).

\section{Histopathological study}

Portions of the pancreas from all the experimental groups were fixed $10 \%$ formalin, dehydrated in alcohol and then embedded in paraffin. Microtome sections ( $5 \mu \mathrm{m}$ thickness) were prepared from the Pancreas sample and stained with hematoxylin-eosin dye. The sections were examined for pathological studies.

\section{Statistical analysis}

The results are expressed as mean \pm standard error mean (SEM). The results were analyzed by one-way ANOVA followed by Tukey's multiple range test using graph pad prism 3.10 versions values $<0.05$ were considered as statistically significant.

\section{RESULTS}

\section{Preliminary phytochemical analysis}

The preliminary phytochemical analysis reveals that triterpenoids, flavonoids, steroids, glycosides, alkaloids and tannins were present in the ethanolic extract. In the aqueous extract, saponins, flavonoids and alkaloids are present.

\section{Acute toxicity test}

In acute toxicity studies of ethanolic and aqueous extract of Zanthoxylum ovalifolium leaves does not show mortality of animals at the dose level of $2000 \mathrm{mg} / \mathrm{kg}$. Therefore $2000 \mathrm{mg} / \mathrm{kg}$ dose was considered as a $\mathrm{LD}_{50}$. Hence, in the present study $200 \mathrm{mg} / \mathrm{kg}\left(1 / 10^{\text {th }}\right.$ low dose) and $400 \mathrm{mg} / \mathrm{kg}\left(1 / 5^{\text {th }}\right.$ high dose) body weight doses were selected for the antidiabetic study.

\section{Effect on blood glucose level}

The effect of Zanthoxylum ovalifolium leaf extracts on blood glucose level in alloxan-induced diabetes in rats is given in table 1 . The blood glucose level was increased significantly in alloxan-induced diabetic rats as compared with the control rats. In diabetic rats, a significant decrease in blood glucose level was observed after the treatment with different extracts. The ethanolic and aqueous extract of Zanthoxylum ovalifolium showed maximum antidiabetic potential at $21^{\text {st }}$ day treatment; however, these extracts exhibited antidiabetic activity in dose and time-dependent manner.

\section{Effect on lipid profile}

When compared to the normal control group, the serum TC, TG, LDL and VLDL cholesterol levels were increased, whereas the level of HDL cholesterol was reduced by in untreated diabetic rats in table 2 . After treatment of ethanolic and aqueous extract of Zanthoxylum ovalifolium for $21 \mathrm{~d}$, the serum TC, TG, LDL and VLDL cholesterol level were reduced significantly, whereas the level of serum HDL cholesterol was significantly increased in time and dose-dependent fashion.

\section{Histopathological study of rat pancreas}

The microscopic structures of rat pancreas in different groups are shown in fig. 1. The pancreas of a normal control rats showed normal islets and pancreatic $\beta$-cells; however, in diabetic control rats, the islets are disrupted islet of langerhans exhibited hydrophobic cells, necrotic cells, vacuolization and irregular hyperchromic nuclei. The ethanolic extract of Zanthoxylum ovalifolium at the dose of $400 \mathrm{mg} / \mathrm{kg} \mathrm{b}$. w. shows a more regeneration of $\beta$-cells in the histopathological slides when compared to EEZO $200 \mathrm{mg} / \mathrm{kg}$, AEZO $200 \mathrm{mg} / \mathrm{kg}$ and AEZO 400 $\mathrm{mg} / \mathrm{kg}$. 
Table 1: Effect of Zanthoxylum ovalifolium leaf extracts on blood sugar level in alloxan-induced diabetes in rats

\begin{tabular}{lllll}
\hline Treatment & $\begin{array}{l}\text { Dose } \\
\mathbf{~ m g / k g}\end{array}$ & \multicolumn{3}{l}{ Blood glucose (mg/dl) } \\
\cline { 3 - 5 } & - & $\mathbf{0}^{\text {th }} \mathbf{d}$ & $\mathbf{7}^{\text {th }} \mathbf{d}$ & $\mathbf{1 4}^{\text {th }} \mathbf{d}$ \\
\hline Normal control & & $346.11 \pm 1.36$ & $104.4 \pm 1.60$ & $108.56 \pm 0.62$ \\
Diabetic control & 5 & $334.70 \pm 1.59$ & $361.43 \pm 3.62$ & $372.66 \pm 3.13$ \\
Glibenclamide & 200 & $333.10 \pm 2.72^{\text {ns }}$ & $260.26 \pm 1.33$ & $143.83 \pm 1.99$ \\
EEZO & 400 & $327.33 \pm 0.91^{\text {ns }}$ & $272.52 \pm 2.16$ & $206.40 \pm 1.75^{* *}$ \\
EEZO & 200 & $341.75 \pm 2.39^{\text {ns }}$ & $277.26 \pm 5.12^{* *}$ & $224.41 \pm 1.48^{* * *}$ \\
AEZO & 400 & $331.17 \pm 1.65^{\text {ns }}$ & $286.18 \pm 1.72$ & $123.50 .5 \pm 1.06$ \\
AEZO & & $279.78 \pm 2.08^{*}$ & $233.66 \pm 1.35^{*}$ \\
\hline
\end{tabular}

Data are expressed as mean $\pm S E M ; n=6$. One-way ANOVA followed by Tukey's multiple comparison test when compared with normal control, ${ }^{*} \mathrm{p}<0.05,{ }^{* *} \mathrm{p}<0.01,{ }^{* * *} \mathrm{p}<0.001$ significant.

Table 2: Effect of Zanthoxylum ovalifolium on serum lipid profile in diabetic rats

\begin{tabular}{|c|c|c|c|c|c|c|}
\hline Treatment & Dose mg/kg & TC & TG & HDL & LDL & VLDL \\
\hline Normal control & - & $81.2 \pm 1.03$ & $72.0 \pm 1.20$ & $39.4 \pm 0.90$ & $45.4 \pm 1.50$ & $15.9 \pm 1.46$ \\
\hline Diabetic control & - & $179.4 \pm 1.03$ & $145.2 \pm 0.81$ & $28.9 \pm 1.47$ & $188.7 \pm 0.85$ & $32.8 \pm 0.91$ \\
\hline Glibenclamide & 5 & $125.1 \pm 0.96$ & $114.8 \pm 1.65$ & $36.6 \pm 1.06$ & $109.4 \pm 1.47$ & $30.4 \pm 1.53$ \\
\hline EEZO & 200 & $88.8 \pm 1.07^{* *}$ & $77.6 \pm 077^{*}$ & $46.8 \pm 1.20^{* *}$ & $51.6 \pm 0.68^{*}$ & $22.5 \pm 0.77^{* *}$ \\
\hline EEZO & 400 & $88.7 \pm 1.77^{* *}$ & $90.0 \pm 1.20^{* * *}$ & $53.5 \pm 1.67^{* * *}$ & $53.5 \pm 1.66^{* *}$ & $27.9 \pm 1.23^{* * *}$ \\
\hline AEZO & 200 & $88.6 \pm 1.15^{* *}$ & $78.9 \pm 0.95^{* *}$ & $42.8 \pm 1.04$ & $52.8 \pm 1.58 * *$ & $21.3 \pm 1.22^{*}$ \\
\hline AEZO & 400 & $88.8 \pm 0.98^{* *}$ & $87.5 \pm 0.97^{* * *}$ & $46.0 \pm 1.63^{*}$ & $59.0 \pm 1.22^{* * *}$ & $23.4 \pm 0.72^{* *}$ \\
\hline
\end{tabular}

Data are expressed as mean \pm SEM; $n=6$. One-way ANOVA followed by Tukey's multiple comparison test when compared with normal control, ${ }^{*} \mathrm{p}<0.05,{ }^{* *} \mathrm{p}<0.01,{ }^{* * *} \mathrm{p}<0.001$ significant.
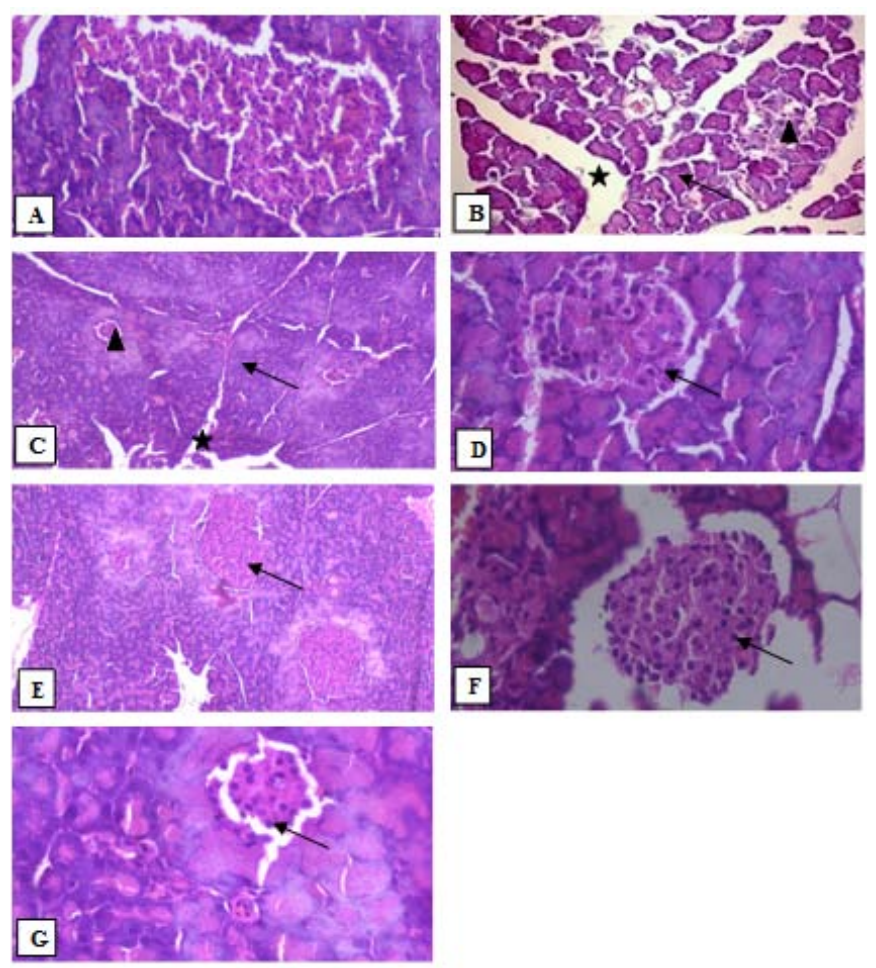

Fig. 1: Histopathology of pancreas in alloxan-induced diabetic rats. A. Control group showing the normal architecture of the pancreas. The exocrine constituent systems of pancreas closely packed by acinar cells and arranged into small lobules. Pancreatic lobules detached by intactintra lobular and interlobular connective tissue septa. The islet cells are seen interspersed between the acinar cells. The islets appeared lightly stained than the surrounding acinar cells. B. Diabetic rats revealed pathological changes of both exocrine and endocrine components.

Theacinar cells were swollen and small vacuoles were observed in almost all acinar cells. Interlobular ducts were lined with flattened epithelium (indicated by black triangle). Islet $\beta$-cells are almost fully lost in alloxanmonohydrate treated rats. C. Diabetic rats treated with Glibenclamide (5 $\mathrm{mg} / \mathrm{kg}$ ) showing distortion of the general architecture. Most exocrine acini revealed acinar damage represented by cytoplasmic vacuolation and

cell atrophy (indicated by black triangle). Wider interlobular (marked by black arrow) and intralobular (marked by black star) duct was observed. D. Diabetic rats treated with EEZO $(200 \mathrm{mg} / \mathrm{kg}$ ) displaying nearly normal structure of Islets of Langerhans. Atrophic change of the acinar cells was less severe and the border between exocrine and endocrine portions became more distinct. E. Diabetic rats treated with EEZO $(400 \mathrm{mg} / \mathrm{kg})$ shown rejuvenation of islets. The small vacuoles in the basal area of acinar cells were also much smaller. F. Diabetic rats treated with AEZO $(200 \mathrm{mg} / \mathrm{kg})$ shown rejuvenation of islets. The small vacuoles in the basal area of acinar cells were also much smaller. G. Diabetic rats treated with AEZO $(400 \mathrm{mg} / \mathrm{kg})$ shown displaying the nearly normal structure of Islets of Langerhans. Atrophic change of the acinar cells was comparatively severe and the border between exocrine and endocrine portions became more distinct 


\section{DISCUSSION}

The various numbers of plants have been traditionally used to treat diabetes and some have been proven to have hypoglycemic effects. These studies have identified that compounds such as polysaccharides [16], flavonoids [17], terpenoids and tannins [18] and steroids [19] are responsible for the antidiabetic effect. The Zanthoxylumovalifolium also contains flavonoids, saponins and carbohydrate, steroids, tannins, and phenolic compounds. The observed hypoglycemic effects of this plant could have resulted from the combined activity of these compounds present in the extract.

Alloxan is one of the usual substances used for the induction of diabetes mellitus apart from streptozotocin. Alloxan has a destructive effect on the beta cells of the pancreas [20,21]. Alloxan causes a massive reduction in insulin release by the destruction of $\beta$ cells the islets of langerhans, thereby inducing hyperglycemia. Insulin deficiency leads to various metabolic alterations in the animals viz increased blood glucose, increased cholesterol, increased levels of alkaline phosphate and transaminases [22-24].

The ethanol and aqueous extract of Zanthoxylum ovalifolium was found to be effective in normalizing the elevated levels of blood glucose and blood lipid-like cholesterol, triglycerides, LDL and VLDL. Administration of alloxan $(100 \mathrm{mg} / \mathrm{kg} \mathrm{i}$. p) led to an elevation of fasting blood glucose levels, which was maintained throughout the period of $21 \mathrm{~d}$ of daily treatment of EEZO and AEZO led to a fall in blood sugar levels. In our studies, the disruption of pancreas in alloxan treated diabetic control rats [fig. 1(B)] and regeneration of cells by glibenclamide [fig. 1(C)] was observed. It is found that ethanol and aqueous extract at high dose $(400 \mathrm{mg} / \mathrm{kg})$ is more effective than extract at low dose $(200 \mathrm{mg} / \mathrm{kg})$ of $21^{\text {th }}$ day treatment. The ethanolic and aqueous extract at high dose $(400 \mathrm{mg} / \mathrm{kg})$ is more effective and shows similar curative effect as the standard that is glibenclamide $(5 \mathrm{mg} / \mathrm{kg})$. This could be due to the possibility that some cells are still surviving to act upon by Zanthoxylum ovalifolium extract to exert its insulin-releasing effect.

Histopathological examination (fig. 1) of the pancreas, in the normal control group, the section of pancreas showing well compacted, arranged in cord like manner the cell of endocrine pancreas especially the $\beta$-cells in the center and alpha in the periphery no necrosis were observed. After inducing alloxan, in diabetic control group the islets are disrupted islets of langerhans exhibited hydrophobic cells, necrotic cells, vacuolization and irregular hyperchromic nuclei. Regeneration of cells can be observed in standard drug (glibenclamide) treated group. In the ethanolic extract of Zanthoxylum ovalifolium $(200 \mathrm{mg} / \mathrm{kg})$ showing necrotic $\beta$ cells and congestive changes with loss of cytochromic granules. The well-formed compactly arranged $\beta$-cells surrounded by alpha cells also note the presence of small highlight indicative of regeneration has been observed in the ethanolic extract of Zanthoxylum ovalifolium $(400 \mathrm{mg} / \mathrm{kg})$. In aqueous extract of Zanthoxylum ovalifolium $(200 \mathrm{mg} / \mathrm{kg})$ the islet of langerhans showing on set of necrotic changes in some of the $\beta$-cells also note the granular cytoplasm indicating presence of insulin granules. The Presence of small highlight and pancreatic duct in the adjacent area indication of ductular hyperplasia and regeneration has been observed in aqueous extract of Zanthoxylum ovalifolium ( $400 \mathrm{mg} / \mathrm{kg})$.

\section{CONCLUSION}

It can be concluded from the present investigations that ethanol and aqueous extracts of Zanthoxylum ovalifolium at high dose $(400 \mathrm{mg} / \mathrm{kg})$ exhibited significant antihyperglycemic activity than at low dose $(200 \mathrm{mg} / \mathrm{kg})$ in alloxan-induced diabetic rats. These test extracts also showed improvement in parameters like lipid profile as well as regeneration of cells in the pancreas. However, further studies are needed to investigate and elucidate the possible mechanism of action of the active ingredients, establish complete safety profiles and evaluate the potential value of Zanthoxylum ovalifolium leaf extracts for the management of diabetes and hyperlipidemia.

\section{ACKNOWLEDGEMENT}

The authors are thankful to Principal, National College of Pharmacy, Shivamogga, Karnataka for providing the facilities to carry out research work.

\section{FUNDING}

Nil

\section{AUTHORS CONTRIBUTIONS}

Both authors have contributed equally.

\section{CONFLICTS OF INTERESTS}

Declared none

\section{REFERENCES}

1. Mohan H. Textbook of pathology. $7^{\text {th }}$ ed. Jaypee Brothers medical publishers, New Delhi; 2015. p. 808-9.

2. Imam K. Clinical features diagnostic criteria and pathogenesis of diabetes mellitus. Springer, New York; 2013. p. 340-55.

3. Elosta A, Ghous T, Ahmed N. Natural products as anti-glycation agents: possible therapeutic potential for diabetic complications. Curr Diabetes Rev 2012;8:92-108.

4. Patel DK, Prasad SK, Kumar R, Hemlatha S. An overview on antidiabetic medicinal plants having insulin mimetic property. Asian Pac J Trop Biomed 2012;2:320-30.

5. International Diabetes Federation (IDF). Diabetes Atlas. $6^{\text {th }}$ Ed. International Diabetes Federation (IDF); 2013.

6. Patel DK, Kumar R, Laloo D, Hemalatha S. Natural medicines from plant source used for therapy of diabetes mellitus: an overview of its pharmacological aspects. Asian Pac J Trop Dis 2012;2:239-50.

7. Preetha PP, Devi VG, Rajamohan T. Effects of coconut water on carbohydrate metabolism and pancreatic pathology of alloxan induced diabetic rats. Eur J Integr Med 2013;5:234-40.

8. Ashok Kumar BS, Lakshman K, Jayaveea KN, Sheshadri Shekar D, Khan S, Thippeswamy BS, et al. Antidiabetic, antihyperlipidemic and antioxidant activities of methanolic extract of Amaranthusviridis linn in alloxan induced diabetic rats. Exp Toxicol Pathol 2012;64:75-9.

9. Negi JS, Bisht VK, Bh AK, Singh P, Sundriyal RC. Chemical constituents and biological activities of the genus Zanthoxylum: a review. Afr J Pure Appl Chem 2011;5:412-6.

10. Medhi K, Deka M, Bhau BS. The genus Zanthoxylum-a stockpile of biological and ethnomedicinal properties. Open Access Sci Reports 2013;2:697-704

11. Khandelwal KR. Practical pharmacognosy. $1^{\text {st }}$ ed. Nirali publications, Pune; 1995. p. 140-3.

12. Kokate CK, Purohit AP, Gokhale SB. Practical pharmacognosy. $4^{\text {th }}$ ed. Nirali Publications, Pune; 2005. p. 108-11.

13. OECD Guidelines for the testing of chemicals, acute oral toxicity-Up-and-down-procedure (UDP), OECD/OCDE 425; 2008.

14. Parthiban P, Ravikumar J, Anjana A. Antidiabetic activity of kovaikizhanguchooranam in alloxan induced diabetic rats. Int J Life Sci Pharm Res 2012;2:68-72.

15. Chaurasia S, Saxena RC, Chaurasia ID, Shrivastav R. Antidiabetic activity of Luffaaegyptica (Mill) in alloxan induced diabetic rats. J Chem Pharm Res 2011;3:522-5.

16. Tomoda M, Shimada K, Konno C, Hikino H. Structure of Panaxan B., A. Hypoglycaemic glycan of Panax ginseng roots. Phytochemistry 1985;24:2431-3.

17. Khanna P, Jain SC. Hypoglycaemic activity of polypeptide-p from a plant source. J Nat Prod 1981;44:648-55.

18. Reher G, Slijepcevic M, Krans L. Hypoglycemic activity of triterpenes and tannins from Sarcopoteriumspinosum and two sanguisorba species. Planta Med 1991;57:57-8.

19. Schimizu M, Ito $T$, Rshima $S$, Mayashi $T$, Arisawa MM, Kurokowa $\mathrm{S}$, et al. Inhibition of lens aldose reductase by flavonoids. Phytochemistry 1984;23:1885-8.

20. Shankar M, Suthakaran. Antidiabetic activity of hydroalcoholic extract of EugeniaJambolana leaves in alloxan induced diabetic rats. Int J Pharm Pharm Sci 2014;6 Suppl 10:138-40.

21. Ramesh C, Prameela Rani A. In vivo and in vitro evaluation of Tephrosia Calophylla for antidiabetic properties. Int J Pharm Pharm Sci 2018;10:138-44.

22. Samir Derouiche, Manel Azzi, Abir Hamida. Effect of extracts aqueous of PhragmitesAustralis on carbohydrate metabolism, 
some enzyme activities and pancreatic islet tissue in alloxan induced diabetic rats. Int J Pharm Pharm Sci 2017;9 Suppl 6:54-8.

23. Jelodar G, Mohsen M, Shahram S. Effect of walnut leaf, coriander and pomegranate on blood glucose and histopathology of pancreas of alloxan-induced diabetic rats.
African J Traditional Complementary Alternative Med 2003;3:299-305.

24. Grover JK, Vats V, Rathi SS. Antihyperglycemic effect of Eugeniajambolana and Tinosporacordifolia in experimental diabetes and their effects on key metabolic enzymes involved in carbohydrate metabolism. J Ethnopharmacol 2000;73:461-70. 